\title{
Preventing Side Shoot Development with C8/C10 Fatty Acids Increases Yield and Reduces Pruning Time in Greenhouse Tomato
}

Logan S. Logendra, Thomas J. Gianfagna, and Harry W. Janes

Plant Biology Department, Rutgers-The State University of New Jersey, 59 Dudley Road, New Brunswick, NJ 08901-8520

Additional index words. octanoic acid, decanoic acid, lateral buds, reproductive growth

Abstract. A mixture of C8/C10 fatty acid methyl esters (FAME) when applied directly and exclusively to leaf axils of greenhouse-grown tomato (Lycopersicon esculentum Mill.) significantly inhibited side shoot development. Plants grown in a single cluster production system in winter produced 8.9 side shoots/plant, whereas those treated with $\mathrm{C} 8 / \mathrm{C} 10$ FAME 45 days after sowing, produced only 0.7 side shoots/plant. Total pruning weight of the side shoots was reduced from $40.2 \mathrm{~g} /$ plant to $1.3 \mathrm{~g} / \mathrm{plant}$. Fruit yield increased $14 \%$ with $\mathrm{C8} / \mathrm{C10}$ FAME treatment and there was an increase in the harvest index from 0.63 to 0.70 . For a spring crop, in which average daily irradiance was more than twice that in winter, overall yield increased $70 \%$ when compared to the winter crop. As in winter, side shoot number and side shoot weight/plant were significantly reduced by C8/C10 FAME, but there was no difference in crop yield between C8/C10 FAME and untreated plants. In both winter and spring, untreated plants required hand pruning three times during the production period, whereas $\mathrm{C8} / \mathrm{C10}$ FAME-treated plants were pruned only once at the time of application. A C8/C10 free fatty acid (FA) mixture was also applied to one and two-cluster plants with similar results. In the multiple cluster system, application of the $\mathrm{C8} / \mathrm{C10} \mathrm{FA}$ mixture instead of side shoot pruning reduced plant height and increased yield from 6.4 to $7.4 \mathrm{~kg} /$ plant. C8/C10 FA or C8/C10 FAME treatment could be a useful labor saving strategy in greenhouse tomato production and may increase crop yield under conditions in which assimilates may be limited by environmental factors, or as a result of a high level of competition from other fruits or shoots.

At about the time the first flowers have opened, and after an initial period of monopodial growth, the tomato (Lycopersicon esculentum Mill.) grows sympodially with the development of numerous lateral shoots. Manual removal of these shoots is an expensive labor-intensive practice that is required for greenhouse production as the lateral shoots compete with developing fruits for nutrients and assimilates, and may also shade both the source leaves, reducing photosynthesis, and the flowers, reducing fruit set. Navarrete and Jeannequin (2000) found that the optimal pruning interval to prevent reductions in crop yield was 7 to $14 \mathrm{~d}$. Nevertheless, manual shoot removal often damages some of the plants and can potentially spread disease. The use of growth regulators to inhibit lateral shoot development in order to limit the number of required pruning operations during crop growth, could reduce costs associated with crop production and may even increase crop yield. Application of abscisic acid, for example, inhibits lateral bud growth, although in tomato it does not suppress growth completely, even when applications are continuously repeated (Tucker and Maw, 1975). Aminoethoxyvinylglycine (AVG), a potent inhibitor of ethylene synthesis, also represses lateral bud development (Yeang

Received for publication 6 Jan. 2004. Accepted for publication 12 Apr. 2004. We thank Joe W. Willis and Russell L. Wright for technical assistance. and Hillman, 1982). Indole acetic acid (IAA), produced in the apical bud and transported basipetally down the stem, imposes lateral bud dormancy in most plants. Canaline, an amino acid similar in structure to AVG, promoted auxin transport in tomato, and suppressed lateral shoot growth (Brenner et al., 1987). Inhibitors such as canaline or AVG may, therefore, prevent lateral bud growth directly by suppressing cell division in the bud, or indirectly by increasing IAA-mediated apical dominance. Even if these treatments were successful, however, there may be adverse effects on flowering, fruit set, and fruit growth, and there may be a need for multiple applications to the same leaf axil over time. In this regard, chemical pruning agents that kill lateral buds and their meristems by contact may be more useful. Off-Shoot-O is a mixture of fatty acid methyl esters that has been used successfully to prevent side shoot growth after topping in tobacco (Steffens et al., 1967) by disrupting plant cell membranes in surface layer cells, without penetrating deeply into the tissue. When the nodal regions of the stem are treated, the meristematic tissue that will give rise to side shoots is killed, but the vascular tissue below remains functional (Wheeler, et al. 1991). Tucker and Maw (1975) tested this product on tomato seedlings and obtained excellent control of side shoots, although $\mathrm{C} 8 / \mathrm{C} 10$ fatty acid methyl esters (FAME) must be applied directly to the leaf axils, avoiding contact with leaves and reproductive organs. Surprisingly, there have been no reports on the effect of $\mathrm{C} 8 / \mathrm{C} 10$ FAME on crop yield in the tomato.

Limited cluster production systems for greenhouse-grown tomatoes are being evaluated because they allow for greater automation of production and more effective use of supplemental lighting during crop growth (Janes and McAvoy, 1991; Logendra et al., 2001). Moreover, insect and disease control are simplified since crops are more rapidly cycled in and out of production. A limitedcluster system should also maximize the labor saving benefits of using a chemical pruning agent since it may be possible to control all side shoot growth with a single treatment. The experiments in this paper were designed to compare the effects of C8/C10FAME and free fatty acids (FA) application with hand pruning of side shoots for one, two and multiple cluster greenhouse tomato crops grown in winter or spring lighting conditions.

\section{Materials and Methods}

One- and two-cluster tomato experiments. Seeds ('Laura') were sown in rockwool (RW) plugs $(2.5 \times 2.5 \times 3.8 \mathrm{~cm})$, watered, and kept at $25^{\circ} \mathrm{C}$. After germination ( $7 \mathrm{~d}$ after sowing) seedlings were irrigated with a nutrient solution containing the following elements: $\mathrm{N}\left(\right.$ as $\left.\mathrm{NO}_{3}\right)$ at $172 \mathrm{mg} \cdot \mathrm{L}^{-1}, \mathrm{P}$ at $52 \mathrm{mg} \cdot \mathrm{L}^{-1}, \mathrm{~K}$ at $381 \mathrm{mg} \cdot \mathrm{L}^{-1}$, $\mathrm{Ca}$ at $177 \mathrm{mg} \cdot \mathrm{L}^{-1}, \mathrm{Mg}$ at $45 \mathrm{mg} \cdot \mathrm{L}^{-1}, \mathrm{Fe}$ at 0.7 $\mathrm{mg} \cdot \mathrm{L}^{-1}, \mathrm{Mn}$ at $0.2 \mathrm{mg} \cdot \mathrm{L}^{-1}, \mathrm{Zn}$ at $0.04 \mathrm{mg} \cdot \mathrm{L}^{-1}$, $\mathrm{Cu}$ at $0.01 \mathrm{mg} \cdot \mathrm{L}^{-1}, \mathrm{~B}$ at $0.13 \mathrm{mg} \cdot \mathrm{L}^{-1}$, and $\mathrm{Mo}$ at $0.06 \mathrm{mg} \cdot \mathrm{L}^{-1}$ with a $\mathrm{pH}$ of 5.5 to 6.5 and an $\mathrm{EC}$ of $1.0 \mathrm{mS} \cdot \mathrm{cm}^{-1}$. At $10 \mathrm{~d}$ seedlings were transplanted into RW cubes $(7.6 \times 7.6 \times 6.3$ $\mathrm{cm})$ and grown on aluminum benches $(1.4 \times$ $5.0 \mathrm{~m}$ ) with an ebb and flood irrigation system. Seedlings were spaced $30 \mathrm{~cm}$ apart on a thin sheet of rayon-polyester material that lined the bench. Plants received two irrigations per day with nutrient solution until $35 \mathrm{~d}$ when the irrigation regime was increased to five to seven irrigations daily with an EC of $2.3 \mathrm{mS} \cdot \mathrm{cm}^{-1}$. The aerial portion of the plant was supported with two horizontal layers of galvanized wire mesh netting ( 12 gauge, with $15 \times 20$-cm grids) mounted on the benches at 30 , and at either 60 or $90 \mathrm{~cm}$ above the bench top. At $45 \mathrm{~d}$ (one cluster) or $55 \mathrm{~d}$ (two cluster) any side shoots that had developed were manually pruned and the plants were topped so that there were two leaves above the fruiting cluster(s). Pollination was accomplished by vibrating the flower clusters daily with a leaf-blower during the flowering period. If the outside natural light intensity was $<800 \mu \mathrm{mol} \cdot \mathrm{m}^{-2} \cdot \mathrm{s}^{-1}$, supplemental lighting was provided from high-pressure sodium lamps at an intensity of $80 \mu \mathrm{mol} \cdot \mathrm{m}^{-2} \cdot \mathrm{s}^{-1}$ for $16 \mathrm{~h}$ from 0500 to $2100 \mathrm{HR}$. Light integral measurements were recorded with a datalogger (LI 1000; LI-COR, Lincoln, Nebr.) using quantum sensors located $1 \mathrm{~m}$ above the bench top. The greenhouse was located in New Brunswick, N.J. (40.5N, 74.4W)

Multple-cluster tomato experiment. The greenhouse floor was covered with a weed barrier and perlite bags (PB) $(105 \times 20 \times 10$ $\mathrm{cm})$ were laid on top of it in rows, at a spacing 
Table 1. Comparison of C8/C10 fatty acid methyl esters (+FAME) vs. hand pruning (-FAME) on vegetative and reproductive growth in a single-cluster greenhouse tomato crop grown under winter $\left(10.6 \mathrm{~mol} \cdot \mathrm{m}^{-2} \cdot \mathrm{d}^{-1}\right)$ or spring $\left(25.1 \mathrm{~mol} \cdot \mathrm{m}^{-2} \cdot \mathrm{d}^{-1}\right)$ lighting conditions.

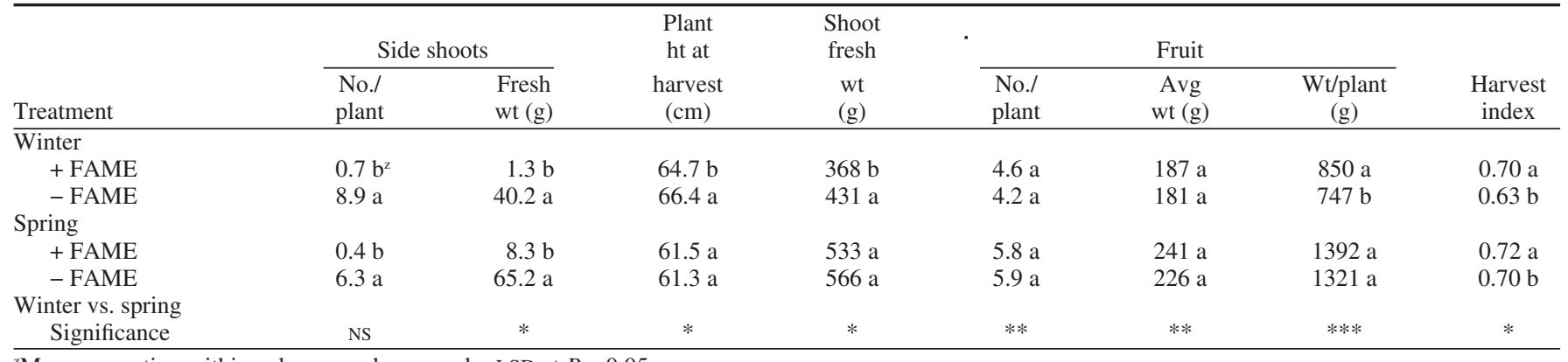

${ }^{2}$ Mean separation within columns and seasons by LSD at $P \leq 0.05$.

Ns, ,**,***** Nonsignificant or significant at $P \leq 0.05,0.01$ or 0.001 respectively.

of $1.65 \mathrm{~m}$. Two slits were made on either side of the PB about $2.5 \mathrm{~cm}$ above the bottom in order to provide adequate drainage. Tomato seedlings in RW plugs ('Rapsidee', four per bag) were transplanted in the PB by making cross-slits on top of the bag at a spacing of $20 \mathrm{~cm}$. Each PB had four emitters (one per seedling) and the seedlings were irrigated with nutrient solution $\left(2.3 \mathrm{mS} \cdot \mathrm{cm}^{-1}\right)$ for 1 to 3 min hourly from 0500 to $1900 \mathrm{HR}$. Plants were trained to grow on twine connected to an overhead wire supported cable system with two cables for each row, $60 \mathrm{~cm}$ apart at a height of $3.3 \mathrm{~m}$. Twenty plants were either manually pruned or the newly appearing nodes were treated with C8/C10 FA $(0.5 \%$ w/v) weekly. Bees were introduced in the greenhouse on a monthly basis to pollinate flowers. Harvesting was carried out twice weekly.

For all experiments, the greenhouse was maintained at $24^{\circ} \mathrm{C}$ day $/ 20^{\circ} \mathrm{C}$ night air temperature. Fruits were harvested at the pink stage. Data were subjected to analysis of variance for a randomized complete-block experiment with two treatments (C8/C10FAME or FA and control), four plants/treatment per block with eight blocks. Means were separated by LSD test. C8/C10FAME $(0.625 \%$ w/v) (Off-Shoot$\mathrm{O}$, The Cochran Corp., Memphis, Tenn.) or C $8 / \mathrm{C} 10 \mathrm{FA}(0.5 \% \mathrm{w} / \mathrm{v})$ (KIC Chemicals, Inc., Armonk, N.Y.) were dissolved in $1.25 \%(\mathrm{w} / \mathrm{v})$ Na Alginate (Kelgin MV, ISP Technologies Inc., Wayne, N.J.) to increase the viscosity of the treatment solutions. A red food coloring dye was added just before application to mark the nodes that were treated.

\section{Results and Discussion}

One-cluster tomato experiment. Under winter lighting conditions, C8/C10 FAME treatment reduced side shoot production from 8.9 to 0.7 side shoots/plant during the production period for a single cluster tomato crop (Table 1). Total side shoot weight and total vegetative growth were significantly reduced as well. In contrast, fruit yield increased by $14 \%$ with C8/C10 FAME treatment, clearly demonstrating the inhibitory influence of side shoot development on fruit growth, despite the fact that no side shoots were allowed to grow for $>10$ d before pruning. All plants were manually pruned at $45 \mathrm{~d}$, but untreated plants required two additional manual pruning operations to

Table 2. Comparison of $\mathrm{C}_{8}$ and $\mathrm{C}_{10}$ fatty acids (+FA) vs. hand pruning (-FA) on vegetative and reproductive growth and number of additional hand prunings in a single-cluster greenhouse tomato crop grown under winter $\left(9.4 \mathrm{~mol} \cdot \mathrm{m}^{-2} \cdot \mathrm{d}^{-1}\right)$ or spring $\left(15.1 \mathrm{~mol} \cdot \mathrm{m}^{-2} \cdot \mathrm{d}^{-1}\right)$ lighting conditions.

\begin{tabular}{|c|c|c|c|c|c|c|}
\hline \multirow[b]{2}{*}{ Treatment } & \multicolumn{2}{|c|}{ Side shoots } & \multicolumn{3}{|c|}{ Fruit $^{\sharp}$} & \multirow{2}{*}{$\begin{array}{c}\text { No. of } \\
\text { additional } \\
\text { hand } \\
\text { prunings }\end{array}$} \\
\hline & $\begin{array}{l}\text { No./ } \\
\text { plant }\end{array}$ & $\begin{array}{c}\text { Fresh } \\
(\mathrm{g})\end{array}$ & $\begin{array}{l}\text { No./ } \\
\text { plant }\end{array}$ & $\begin{array}{c}\text { Avg } \\
\text { wt (g) }\end{array}$ & $\begin{array}{c}\text { Wt/plant } \\
\text { (g) }\end{array}$ & \\
\hline \multicolumn{7}{|l|}{ Winter } \\
\hline$+\mathrm{FA}$ & $1.9 \mathrm{~b}^{\mathrm{z}}$ & $362 \mathrm{a}$ & $4.1 \mathrm{a}$ & $185 \mathrm{a}$ & $739 a$ & 0 \\
\hline$-\mathrm{FA}$ & $12.1 \mathrm{a}$ & $116 \mathrm{~b}$ & $4.6 \mathrm{a}$ & $192 \mathrm{a}$ & $867 \mathrm{a}$ & 2 \\
\hline \multicolumn{7}{|l|}{ Spring } \\
\hline$+\mathrm{FA}$ & $1.9 \mathrm{~b}$ & $157 \mathrm{a}$ & $6.5 \mathrm{a}$ & $250 \mathrm{a}$ & $1530 \mathrm{a}$ & 1 \\
\hline$-\mathrm{FA}$ & $13.0 \mathrm{a}$ & $206 \mathrm{a}$ & $7.0 \mathrm{a}$ & $249 \mathrm{a}$ & $1503 \mathrm{a}$ & 2 \\
\hline \multicolumn{7}{|l|}{ Winter vs. spring } \\
\hline Significance & NS & $*$ & $* *$ & $* *$ & $* *$ & \\
\hline
\end{tabular}

${ }^{2}$ Mean separation within columns and seasons by LSD at $\mathrm{P} \leq 0.05$.

NS,*,** Significant at $\mathrm{P} \leq 0.05$, or 0.01 respectively.

remove side shoots. Most of the pruning weight was removed at $55 \mathrm{~d}$, which coincided with the period of flowering and fruit set. $\mathrm{C} 8 / \mathrm{C} 10$ FAME-treated plants did not require additional pruning although at harvest some plants had small side shoots ( 0.7 side shoots/plant, $1.3 \mathrm{~g}$ fresh weight). Untreated plants were slightly but significantly taller (Table 1) suggesting that the presence of rapidly growing side shoots contributes to internode elongation, perhaps via basipetal auxin transport from the apical bud of the side shoot to the elongating internode. The coincidence of fruit set with significant side shoot development suggests that side shoots may compete directly with the fruit for assimilates during a critical stage in fruit development and/or that the side shoots produce hormones that interfere with fruit cell division or enlargement. For tomato, cell division in the ovary occurs only for 10 to 12 d after flower anthesis (Atta-Aly et al., 1999), so it may be especially sensitive to inhibitory influences of the side shoots. The increase in fruit yield and the reduction in total vegetative growth with $\mathrm{C} 8 / \mathrm{C} 10 \mathrm{FAME}$ treatment resulted in an increase in the harvest index (HI) from 0.63 to 0.70

Under spring lighting conditions, side shoot number and weight were also reduced considerably by $\mathrm{C} 8 / \mathrm{C} 10$ FAME treatment, however; there was no effect on fruit yield. Average greenhouse day/night temperature were similar between the winter and spring crops, but there was more than a 2 -fold increase in average spring daily irradiance. Plants grown in the spring were not as tall as in winter, produced fewer side shoots with greater side shoot weight, and had greater total vegetative growth. Fruit yield was $70 \%$ greater as a result of increases in both fruit number/plant and average fruit weight. The HI was also significantly higher in spring (Table 1). Most likely, the higher levels of irradiance allowed for greater photosynthesis providing adequate assimilates for both side shoot growth and fruit development (McAvoy and Janes, 1989). High light levels may also have promoted fruit set (Rodriguez and Lambeth, 1975). While there was no yield increase with C8/C10FAME treatment in spring, there was still a considerable saving in labor, since untreated plants required two additional pruning operations.

The free C8/C10 FA are also effective chemical pruning agents. When applied to single cluster tomato plants under winter and spring lighting conditions side shoot number/ plant was significantly reduced (Table 2 ). In this experiment, however, fruit yield components and total fruit yield were not significantly different between treatments. The C8/C10 FA treatments did not require additional hand pruning after application to the leaf axils at 45 $\mathrm{d}$ from sowing. In contrast, untreated plants required two additional hand pruning treatments before harvest.

The C8/C10 FA appear to penetrate more deeply into the leaf axil than the FAME and can cause the petiole to collapse at the point of treatment. This problem can be avoided by applying a lower rate of the FA $(0.5 \%$ vs. $0.625 \%$ ), but the margin of safety is still less than with the FAME.

Two-cluster tomato experiment. For a twocluster crop under both winter and spring light- 
Table 3. Comparison of $\mathrm{C}_{8}$ and $\mathrm{C}_{10}$ fatty acids $(+\mathrm{FA})$ vs. hand pruning $(-\mathrm{FA})$ on vegetative and reproductive growth and pruning or treatment time in a two-cluster greenhouse tomato crop grown under winter $\left(7.7 \mathrm{~mol} \cdot \mathrm{m}^{-2} \cdot \mathrm{d}^{-1}\right)$ and spring lighting conditions $\left(14.8 \mathrm{~mol} \cdot \mathrm{m}^{-2} \cdot \mathrm{d}^{-1}\right)$.

\begin{tabular}{|c|c|c|c|c|c|c|c|c|}
\hline \multirow[b]{2}{*}{ Treatment } & \multicolumn{2}{|c|}{ Side shoots } & \multicolumn{3}{|c|}{ Fruit } & \multirow{2}{*}{$\begin{array}{c}\text { No. of } \\
\text { additional } \\
\text { hand } \\
\text { prunings }\end{array}$} & \multirow{2}{*}{$\begin{array}{l}\text { Pruning or } \\
\text { treatment } \\
\text { time/plant } \\
\text { (s) }\end{array}$} & \multirow{2}{*}{$\begin{array}{c}\text { Plant } \\
\mathrm{ht}^{\mathrm{z}} \\
(\mathrm{cm})\end{array}$} \\
\hline & $\begin{array}{l}\text { No./ } \\
\text { plant }\end{array}$ & $\begin{array}{l}\text { Fresh } \\
\text { wt }(g)\end{array}$ & $\begin{array}{l}\text { No./ } \\
\text { plant }\end{array}$ & $\begin{array}{c}\text { Avg wt } \\
\text { (g) }\end{array}$ & $\begin{array}{c}\text { Wt/plant } \\
(\mathrm{g})\end{array}$ & & & \\
\hline \multicolumn{9}{|l|}{ Winter } \\
\hline$+\mathrm{FA}$ & $4.9 b^{y}$ & $33 \mathrm{a}$ & $7.3 \mathrm{a}$ & $178 \mathrm{a}$ & $1308 \mathrm{a}$ & 1 & $31 \mathrm{~b}$ & $\mathrm{ND}^{\mathrm{x}}$ \\
\hline$-\mathrm{FA}$ & $8.3 \mathrm{a}$ & $36 \mathrm{a}$ & $7.1 \mathrm{a}$ & $170 \mathrm{a}$ & $1204 \mathrm{a}$ & 2 & $44 \mathrm{a}$ & ND \\
\hline \multicolumn{9}{|l|}{ Spring } \\
\hline$+\mathrm{FA}$ & $5.1 \mathrm{~b}$ & $297 \mathrm{~b}$ & $9.4 \mathrm{a}$ & $202 \mathrm{a}$ & $1893 \mathrm{a}$ & 1 & ND & $46 \mathrm{~b}$ \\
\hline -FA & $9.0 \mathrm{a}$ & $390 \mathrm{a}$ & $6.6 \mathrm{~b}$ & $223 \mathrm{a}$ & $1435 \mathrm{~b}$ & 2 & ND & $58 \mathrm{a}$ \\
\hline \multicolumn{9}{|l|}{ Winter vs. spring } \\
\hline Significance & NS & $* * *$ & $* *$ & $* * *$ & $* *$ & NS & & \\
\hline
\end{tabular}

z49 Days after sowing.

${ }^{\mathrm{y}}$ Mean separation within columns and seasons by LSD, $P \leq 0.05$.

${ }^{\mathrm{x} D}=$ not determined.

NS, ${ }^{* *}, * * *$ Nonsignificant or significant at $P \leq 0.01$, or 0.001 , respectively.

Table 4. Comparison of $\mathrm{C}_{8}$ and $\mathrm{C}_{10}$ fatty acids (+FA) vs. hand pruning (-FA) on plant height, reproductive growth and pruning or treatment time in a multiple cluster greenhouse tomato crop under spring lighting conditions.

\begin{tabular}{lccccc}
\hline & $\begin{array}{c}\text { Plant } \\
\text { ht }\end{array}$ & \multicolumn{3}{c}{ Fruit $^{\mathrm{z}}$} & $\begin{array}{c}\text { Pruning or } \\
\text { Treatment }\end{array}$ \\
\cline { 3 - 6 } & $(\mathrm{cm})$ & No./ & Avg wt & Wt/plant & $\begin{array}{c}\text { treatment } \\
\text { time/plant }(\mathrm{s})\end{array}$ \\
\hline +FA & $119 \mathrm{~b}^{\mathrm{x}}$ & $40.1 \mathrm{a}$ & $187 \mathrm{a}$ & $7.4 \mathrm{a}$ & $22 \mathrm{a}$ \\
- FA & $132 \mathrm{a}$ & $35.5 \mathrm{a}$ & $183 \mathrm{a}$ & $6.4 \mathrm{~b}$ & $23 \mathrm{a}$ \\
\hline
\end{tabular}

z21 Harvests.

y56 Days after initial FA application.

${ }^{x}$ Mean separation within columns by LSD at $P \leq 0.05$.

ing conditions side shoot numbers for treated and untreated plants were similar to the single cluster experiment with significantly fewer side shoots on C8/C10FA-treated plants (Table 3 ). In the spring, untreated plants required two additional pruning treatments, but only one was needed on the plants receiving the 55 $\mathrm{d}$ C8/C10 FA application. It is not possible to treat all of the leaf axils at $55 \mathrm{~d}$ on twocluster plants so additional hand pruning is required. Nevertheless, there were fewer side shoots than on untreated plants, and the time required to hand prune the treated plants was significantly less. Consistent with the winter C8/C10 FAME experiment (Table 1), plant height was significantly reduced by $\mathrm{C} 8 / \mathrm{C} 10$ FA treatment. Under the spring lighting conditions, fruit yield was almost $32 \%$ greater for the $\mathrm{C} 8 / \mathrm{C} 10 \mathrm{FA}$ treatment. This was due to a significant increase in fruit number/plant. The increased fruit number occurred in cluster two with 4.7 fruits compared to only 3.0 fruit for untreated plants $(P \leq 0.02)$. The fruit set period coincided with significant side shoot development in all treatments, however; side shoot weight was $30 \%$ greater on untreated plants (Table 3), which may have limited fruit set in the second cluster due to competition between vegetative and reproductive growth.

Multiple-cluster tomato experiment. For a conventional multiple cluster greenhouse tomato crop, application of C8/C10FA in place of hand pruning resulted in a $16 \%$ increase in fruit yield over 21 cumulative harvests during a three month time period in spring (Table 4). Treated plants were slightly but significantly shorter, and there was no difference in the amount of time it took to either apply the C8/C10 FA, or to manually prune the plant. Therefore in the multiple cluster system, there were no savings of labor, but there was an increase in crop yield and the shorter plants were easier to manage.

A suitable application device will be required for C8/C10 FA or FAME treatment. Maw (1977) used a felt tip marker filled with treatment solution with good results. We found that making a $\mathrm{C} 8 / \mathrm{C} 10 \mathrm{FA}$ paste with agar or a food grade gel minimized accidental contact with the leaves, and adding a food coloring dye insured that no leaf axils were left untreated. We loaded this mixture in a syringe attached to a repeatable pipette to deliver a constant dose to each leaf axil.

Application of $\mathrm{C} 8 / \mathrm{C} 10 \mathrm{FA}$ or FAME directly and exclusively to the leaf axils of one, two or multiple cluster tomato plants control side shoot production and may reduce the requirements and time for hand pruning. Under conditions in which assimilates may be limited by environmental factors, or as a result of a high level of competition from other fruit, preventing side shoot development can result in increased crop yield.

\section{Literature Cited}

Atta-Aly, M.A., G.S. Riad, Z.S. El-Lacheene, and A.S.El-Beltagy. 1999. Early application of ethrel extends tomato fruit cell division and increases fruit size and yield with ripening delay. J. Plant Growth Regul.18:15-24.

Brenner, M.L., D.J. Wolley, V. Sjut, and D. Salerno. 1987. Analysis of apical dominance in relation to IAA transport. HortScience 22:833-835.

Janes, H.W. and R.J. McAvoy. 1991. Environmental control of a single-cluster greenhouse tomato crop. HortTechnology 1:110-114.

Logendra, L.S., T.J. Gianfagna, D.R. Specca, and H.W. Janes. 2001. Greenhouse tomato limited cluster production systems: Crop management practices affect yield. HortScience 36:893-896.

Maw, G.A. 1977. Aliphatic alcohols as pruningagents for tomato side shoots. Scientia Hort. 7:43-53.

McAvoy, R.J. and H.W. Janes. 1989. Tomato plant photosynthetic activity as related to canopy age and tomato development. J. Amer. Soc. Hort. Sci. 114:478-482.

Navarrete, M. and B. Jeannequin. 2000. Effect of frequency of axillary bud pruning on vegetative growth and fruit yield in greenhouse tomato crops. Scientia Hort. 86:197-210.

Rodriguez, B.P. and V.N. Lambeth. 1975. Artificial lighting and spacing as photosynthetic and yield factors in winter greenhouse tomato culture. J. Amer. Soc. Hort. Sci. 100:694-697.

Steffens, G.L., T.C. Tso, and D.W. Spaulding. 1967. Fatty alcohol inhibition of tobacco axillary and terminal bud growth. J. Agr. Food Chem. 15:972-975.

Tucker, D.J., and G.A. Maw. 1975. Chemical control of side shoots in the tomato. Scientia Hort 3:331-338.

Wheeler, J.J., H. Seltmann, and A.G. Motten. 1991. The mode of action of fatty alcohols in leaf tissue. J. Plant Growth Regulat. 10:129-137.

Yeang, H.Y. and J.R. Hillman. 1982. Lateral bud growth in Phaseolus vulgaris L. and the levels of ethylene in the bud and adjacent tissue. J. Expt. Bot. 33:111-117. 